intervention. Regulation by the government might remove duplication to some extent, but since the milk business would still be operated with profit as the dominant motive, it is questionable whether consumers would receive any substantial benefits.

It is probable that duplication in facilities can be eliminated in fundamental fashion only by some form of government ownership and operation of milk distribution systems. Eminent domain proceedings financed by the issuance of bonds might be instituted against private distributors. Administration could be placed in the hands of a Milk Distribution Authority, composed of representatives of consumers, labor, social agencies, and milk producers. ${ }^{72}$ While the suggested plans have generally contemplated ownership by municipalities, ${ }^{73}$ it may be desirable, though perhaps impracticable, to adopt a system of state or federal ownership in order to attain effective correlation and coordination of facilities. ${ }^{74}$ Government operation carries with it, of course, a danger of political abuse, but at least, in contrast to the present system, those in control of milk distribution would be known by and accountable to the public. And the possibility of political machinations seems worth risking in view of the substantial savings which government ownership would undoubtedly effect.

\title{
MULTIPLE INCORPORATION AS A FORM OF RAILROAD ORGANIZATION
}

ThE IMPENDING announcement of a reorganization plan for the multiplyincorporated New York, New Haven and Hartford Railroad ${ }^{1}$ suggests an inquiry into the wisdom of retaining the multiple corporation as a form of business organization. A multiple corporation is a business unit peculiar to the American scene in which the same group of stockholders have become incorporated in two or more states to carry out the same corporate purposes

milk plant, owned and managed by dairymen, is very feasible and, it is believed, would solve most, if not all of the problems of economical and adequate supply."

72. See N. Y. Times, Feb. 27, 1937, p. 20, col. 4.

73. Ibid; BlACK, op. cit. supra note 42, at 253-255.

74. Report on the More Economic Distribution and Delivery of Milk in the City of Chicago, supra note 71, at 13-14.

1. The New Haven's president reported that the plan should be ready by June 1 . See N. Y. Times, March 30, 1937, p. 31, col. 4. Another multiple corporation, the Wabash Railroad, is also being reorganized. See N. Y. Times, April 8, 1937, p. 38, col. 1. 
and have appointed one set of officers to run the entire organization.? The reasons for their appearance can best be explained by a glance at history.

\section{Historical Developarent}

Of primary significance in the development of this particular type of business organization was the restrictive theory of corporations, that one sovereign state may not grant privileges which will be exercisable in the territory of another. ${ }^{3}$ This theory was formulated by legal scholars of the early days in order to confine within narrow territorial limits the corpora. tions which Congress or the state legislatures might erect, since the grants of special and exclusive privileges or monopolies enjoyed by the great English trading companies, with which the colonists were familiar, conflicted with colonial ideas of natural rights.* Although territorial limitations proved no hardship to most of the early corporations which did no business outside their charter states, the construction of canals, waterways, and interstate bridges offered a field of activity in which the need of corporate institutions transcending state lines was urgently felt. Since constitutional doctrines founded upon comity, the commerce clause, the Fourteenth Amendment, and unconstitutional conditions were not then sufficiently formulated to compel the states to recognize foreign corporations, some form of dual incorporation seemed to be the most practical solution to the problem; therefore, instead of resorting to federal charters, corporations engaged in interstate activities obtained concurrent grants of corporate powers. ${ }^{\circ}$

But railways, unlike waterways and bridges, were not built upon state boundaries; and since the early roads were local in character, the necessity for concurrent chartering in several states did not immediately appear. ${ }^{8}$ As the long haul demonstrated its usefulness, however, the small roads began to extend their lines, and when a corporation desired to operate in

2. See Restatearent, Confuict of Laws (1934) \$203.

3. For an exposition of this theory, see Banle of Augusta v. Earle, 13 Pet 519 (U. S. 1839); Paul v. Virginia, 8 Wall. 168 (U. S. 1869); Yousc, Fonerg:i Conpanies and other CoRporations (1912) c. 2.

4. See 2 Davis, Essays in the Earlier History of Auserica: Corrorntrons (1917) 6; Henderson, Position of Foreign Corforations mi Asierscari ConstituTIONAL LAW (1918) c. 2.

5. See Henderson, op. cit. supra note 4; Comment (1931) 79 U. of PA. L. REv. 956, 1119.

6. In the period from 1781 to 1800 , eleven corporations with two or more charters were formed. Of these six were canal companies, four were bridge companies, and one was the Bank of North America with a federal charter. See 2 DAvs, op. cit. supra note 4, at 30. For an example, see State v. Metz, 32 N. J. L. 199 (1867).

7. See MacGill, History of Transportation (1917) c. 17; Stere:ss, The BEgrnisings of the New York Central Rathroad (1926) 200.

8. Concurrent incorporation of one railway by two states was used in a few instances. E.g., Stone v. Farmers Loan \& Trust Co., 116 U. S. 307, 316 (18S6). 
foreign states, it would customarily obtain additional grants of corporate powers $^{9}$ together with the necessary franchises. ${ }^{10}$ MIultiple incorporation could arise by this method without the consent or even clespite the disapproval of the state first chartering, because the second state has the power to reincorporate even if the corporation has no authority under its first charter to accept a second ${ }^{11}$ and because acceptance of a second charter does not forfeit the first. ${ }^{12}$ But some criterion was needed to determine when the second state had rechartered. During a period when it was uncertain whether or not a foreign corporation might be served with legal process in other than its charter state, the courts were not hesitant to consider all acts authorizing foreign railway corporations to enter the state acts of incorporation so that resident plaintiffs would not have to go into the foreign state to sue. ${ }^{13}$ But after it had become established that a foreign corporation might be served in any state in which it was doing business, the Supreme Court announced that reincorporation occurred only when the statute evidenced a legislative intent to recharter. ${ }^{14}$

Although railroads often reincorporated voluntarily to facilitate the crossing of state lines, voluntary reincorporation was not solely responsible for the creation of multiple corporations in the railroad field. In many instances this form of organization was compelled by state statutes which required foreign corporations, as a condition of doing business in the state, to file a copy of their charters and declared them to be domestic corporations. ${ }^{15}$ These domestication statutes, as they have been called, were enacted primarily to prevent the corporations from removing to the federal courts and were the final step in the long though unsuccessful struggle which the states have maintained to retain the exclusive jurisdiction of their own courts. ${ }^{\text {to }}$

9. Sec Nashua \& Lowell R. R. v. Boston \& I. R. R., 136 U. S. 356 (1890); Brocket v. Ohio \& P. R. R., 14 Pa. St. 241 (1850). But see Mead v. New York, H. \& N. R. R., 45 Conn. 199 (1877) (foreign corporation granted a franchise in Connecticut).

10. See 1 Elliott, Railroads (3d ed. 1921) $\$ \S 75,76,79$.

11. Clark v. Barnard, 108 U. S. 436 (1883).

12. Nashua \& Lowell R. R. v. Boston \& L. R. R., 136 U. S. 356 (1890); Commonwealth v. Pittsburg \& C. R. R., $58 \mathrm{~Pa}$. St. 26 (1868); see Restatenent, ConFLICT OF LAWS (1934) $§ 203$.

13. County of Allegheny v. Cleveland \& P. R. R., 51 Pa. St. 228 (1865); Baltimore \& O. R. R. v. Gallahue's Administrator, 12 Gratt. 655 (Va. 1855). Authority to convey assets or lease to a foreign corporation was even said to reincorporate the foreign corporation which accepts the conveyance or lease. Angier v. East Tenn., V. \& G. R. R., 74 Ga. 634 (1885); see Baltimore \& O. R. R. v. Cary, 28 Ohio St. 208, 227 (1876).

14. Baltimore \& O. R. R. v. Harris, 12 Wall. 65 (U. S. 1870).

15. E.g. Miss. Cone Axx. (1930) $\S 4160-2$; Tenn. Laws 1891, c. 122. Some statutes do not declare that the corporation becomes reincorporated but merely state that it shall be subject to state laws in the same manner as a domestic corporation. E.g., TenN. Code ANs. (Williams, 1934) \$4127.

16. See generally, 17 Fletcher, Corporations (1931) $\S 8400$. 
In most states these statutes applied only to certain classes of corporations such as railroads and public utilities ${ }^{17}$ which were further attacked by state constitutional provisions prohibiting all but domestic corporations from exercising within the states special powers such as the power to buy or lease railroads, ${ }^{18}$ to acquire real estate, ${ }^{10}$ or to exercise the privilege of eminent domain. ${ }^{20}$

The majority of the cases involving these statutes have been primarily concerned with the states' power to affect access to the federal courts by compulsory reincorporation. At first the state courts jealously tried to maintain their jurisdiction and, applying the test formulated by the Supreme Court in the case of voluntary reincorporation, declared that there was no diversity because the legislature had intended to recharter the foreign corporation. ${ }^{21}$ For a time the lower federal courts were willing to accept this viem:.22 But in those cases that reached the Supreme Court it was generally held that, although the legislature might recharter, the particular statute in question evidenced no such intent. ${ }^{23}$ All doubts on the subject, however. were dispelled by the case of St. Louis \& San Francisco Railivay z'. Janns, 21 which announced a new rule, now established, ${ }^{25}$ that nothing short of the incorporation of natural persons by a state will result in the creation oi a corporation whose stockholders will be presumed to be citizens of that state for the purposes of federal jurisdiction.

17. E.g., ג. C. Laws 1899, c. 62; Tenn. Laws 1877, c. 31.

18. E.g., S. C. Const. art. 9, \$\$. When the legislature provided a means by which foreign corporations might become domesticated to iulfill the requirentent, the Act was held unconstitutional. Carolina, C. \& O. Ry. v. MLCourn, \&4 S. C. 318, 6in S. E. 418 (1909). A later act whose constitutionality has apparently 11st besu ditz-thued, provides that the stockholders of the forcign railroad hut not the eorporition itsels may apply for a domestic charter. S. C. Cone (1932) \$7777.

19. E.g., Kr. Coxst. \$211. Domestication is provided for by statute. Kr. Sr.st. ANar. (Carroll, 1936) $\$ 765$.

20. E.g., NEB. Coxst. art. $x, \S 8$. Dumestication is provided for by statute VEb. Conr. Stat. (1929) c. $24, \$ 222$. Texas specifically prohibits all foreign corporations from operating railroads in the state but provides no method for their domestication. Tex. Axx. Rev. Civ. Stat. (Vernon, 1925) art. 6260.

21. State v. Chicago, B. \& Q. R. R., 25 Neb. 1E6, 41 N. WV. 125 (18\&S); Debnam v. Southern Bell Tel. Co., 126 X. C. 831, 36 S. E. 269 (1900); Allison v. Southern Ry., 129 స. C. 336,40 S. E. 91 (1901); MLathis v. Southern Ry., 33 S. C. 246, 31 S. E. 240 (1898).

22. Ūphoff v. Chicago, St. L. \& N. O. R. R., 5 Fed. 545 (C. C. D. Ky., 1830); Stout v. Sioux City \& Pac R. R., \& Fed. 794 (C.C.D. Neb. 1881) ; Mfisssuri Pac. Ry. v. Meeh, 69 Fed. 753 (C. C. A. Stil, 1895).

23. Pennswlvania R. R. v. St. Louis, A. \& T. H. R. R., 11 C. S. 290 (18s6); Goodlett v. Louisville \& N. R. K.. 122 U. S. 391 (1887); Mlartin's Administrator *. Baltimore \& O. R. R., 151 L. S. 673 (1894). Contra: Memphis \& C. R. R. v. Alabama, 107 U. S. $5 S 1$ (1SS2).

24. 161 U. S. 545 (1896).

25. Louisville, X. A. \& C. Ry. v. Louisville Trust Co., 174 C. S. 552 (1899); Southern Ry, v. Allison, 190 C. S. 326 (1903): Afissouri Pac. Ry. v. Castle, 224 U. S. 
Some of the cases suggest a distinction between the states' power to domesticate to prevent resort to the federal courts and the power to domesticate for other purposes without enumerating the purposes for which domestication is permissible. ${ }^{26}$ Furthermore, the Supreme Court, in the few decisions that have not involved a question of federal jurisdiction, has held that the state legislature might reincorporate foreign corporations in order to tax them and to confer powers not contained in their original charters. ${ }^{27}$ But a recent Wisconsin decision suggests a situation in which domestication statutes are ineffective to accomplish their purpose by holding that a state may not defeat the Supreme Court's rule against double taxation by the simple expedient of reincorporation. ${ }^{28}$ In view of this decision it may be necessary to qualify the broad statement, recently affirmed by the Supreme Court, that a state may always require reincorporation as a condition of doing intrastate business within its boundaries. ${ }^{20}$

Since compulsory domestication does not create a multiple corporation for all purposes, and since state requirements that certain powers may be exercised only by domestic corporations would probably be met today by the subsidiary device, it seems unlikely that true multiple corporations will in the future be organized by rechartering unless the action on the part of the management is voluntary. But even this possibility is slight since state constitutional prohibitions bar special acts of incorporation.

The main reason for most of the existing multiple corporations was the combination of two railroads incorporated by different states whose lines happened to connect. Since the early railroad charters contained no provisions for the sale of assets and franchises, ${ }^{30}$ and since the potentialities of control through stock ownership had not as yet been realized, statutory consolidation was the method of combination generally used, even though special legislative

541 (1912) ; Carolina \& N. W. R. R. v. Clover, 34 F. (2d) 480 (W. D. S. C. 1929); see Comments (1931) 44 Harv. L. Rev. 1106, (1930) 78 U. of PA. L. Rev. 538.

26. See cases cited supra note 25 .

27. Indianapolis \& S. L. R. R. v. Vance, 96 U. S. 450 (1878); Clark v. Barnard, 108 U. S. 436 (1883) ; see Smith v. N. Y., N. H. \& H. R. R., 96 Fed. 504, 506 (C. C. D. Mass. 1899). Some state decisions are in accord. Ewing v. Warren, 144 Miss. 233, 109 So. 601 (1926); Commonwealth v. United Cigarette Machine Co., 119 Va. 447, 89 S. E. 935 (1916).

28. Newport Co. v. Wis. Tax Commission, 219 Wis. 293, 261 N. W. 884 (1935), (1936) 11 Wis. L. Rev. 300; see Frost, Power of the States to Domesticate Foreign Corporations for Income Tax Purposes (1925) 59 Axr. L. REv. 1; Comment (1931) 44 HaRv. L. REv. 1111. Contra: Commonwealth v. United Cigarette Machine Co., 119 Va. 447,89 S. E. 935 (1916). 1103.

29. Railway Express Agency v. Virginia, 282 U. S. 440 (1931), 40 YALE L. J.

30. Unlike other corporations, prosperous railroads cannot sell their assets and franchises in the absence of legislative authorization. See 1 Elliotr, Rallronds (3d ed. 1921) $\S 82,595$. 
authorization was required. ${ }^{31}$ As the early railroads had no complicated capital structures but were financed almost entirely by the issue of common stock, the consolidation device allowed combination to take place by the simple expedient of calling the stockholders of each corporation stockholders in the other. ${ }^{32}$ These early consolidations were probably little more than contracts for the joint operation of two existing lines, and since most of the early charter authorizations merely conferred the power "to connect and make joint stock" with other railroads, it was natural for the courts to say that the consolidation did not affect the separate corporate entities in each state. ${ }^{33}$ But even though the consolidation statutes became more general and were phrased so as to imply the creation of a single corporation, the courts continued to hold that two corporate entities must result when the organization is effected under the statutes of two states. ${ }^{34}$

Many railroads that became multiple corporations by interstate consolidation have continued to retain that form of corporate organization. ${ }^{35}$ In addition, further consolidations may be achieved under the laws of some states only through the device of multiple incorporation, for several states have not yet granted domestic corporations authority to convey their assets and franchises to foreign corporations. ${ }^{36}$ But a few courts have evidenced a disinclination to hold that interstate consolidations result in multiple incorporation and have called the combination either a merger as distinguished from a consolidation, ${ }^{37}$ or a sale of assets and dissolution of one company, ${ }^{3.3}$ or have said that the intent of the parties to create one corporation shall control, $^{39}$ or that the consolidated corporation was created under foreign law alone. ${ }^{40}$ Furthermore, the most recent statutes avoid multiple incorporation

31. Pearce v. Madison \& I. R. R., 21 How. 441 (U. S. 1859); see 1 ELuorT, RAILROADS (1921) § 370 .

32. E.g., Mass. Laws 1840, c. 50, §1. See Farnum v. Blaclistone Canal Corp., 8 Fed. Cas. No. 4675, at 1062 (C. C. R. I. 1830); Bishop v. Brainerd, 28 Conn. 239, 296 (1859).

33. Shields v. Ohio, 95 U. S. 319 (1877); Bishop v. Brainerd, 28 Conn. 289 (1859).

34. Southern Ry. v. Lancaster, 149 Ga. 434, 100 S. E. 380 (1919); Ohio \& A. Ry. v. People, 123 IIl. 467,14 N. E. 874 (1888).

35. E.g., Elgin, Joliet \& Eastern Ry.; Gulf, Mobile \& Northern R. R.; New York Central R. R.; and New York, New Haven \& Hartford R. R.

36. E.g., Idaho, Kansas, Mississippi, Nevada, and Texas. In some states this privilege is given only in certain circumstances, as when the foreign corporation owns all the stock of or leases the domestic railroad corporation. E.g., ILL REv. Stat. (1935) c. 114, §37 (1); Ind. Stat. ANN. (Burns, 1933) \$ 55-2513.

37. Lee v. Atlantic Coast Line R. R., 150 Fed. 775 (C. C. S. C. 1906), aff'd sub nom., Atlantic Coast Line R. R. v. Dunning, 166 Fed. 850 (C. C. A. 4th, 190S); Royal Palm Soap Co. v. Seaboard Air Line Ry., 296 Fed. 448 (C. C. A. 5th, 1924).

38. Walters v. Chicago, B. \& Q. R. R., 104 Fed. 377 (C. C. Neb. 1900).

39. Eaton \& H. R. R. v. Hunt, 20 Ind. 457 (1863). But cf. Wasley v. Chicago, R. I. \& P. Ry., 147 Fed. 608 (C. C. N. D. Iowa 1906).

40. Westheider v. Wabash R. R., 115 Fed. 840 (C. C. S. D. Ill. 1902). But of. Patch v. Wabash R. R., 207 U. S. 277 (1907); Paul v. Baltimore \& O. \& C. R. R., 
by allowing the consolidated company to choose the state under whose laws it will organize from among the charter states of its constituents. ${ }^{41}$ But the majority of the states still have no such provision, and a tew, perhaps fearing that they will lose control of the consolidation if it becomes a foreign corporation, require that it remain a domestic corporation. ${ }^{42}$

\section{Legal Problexs of Mleltiple Corporations}

Once multiple incorporation has occurred it is important to determine the status of the organization in each charter state. To the business man there is but one corporation chartered in sereral states. But the traditional legal view is otherwise: A separate legal entity is said to result in each charter state, first, because the Constitution prohibits two or more states from making compacts without the consent of Congress ${ }^{43}$ secondly, because, in spite of the full faith and credit clause, notions of sovereignty prevent the laws of one state from having extraterritorial effect; ${ }^{4 t}$ and finally, because the restrictive theory requires corporations to dwell in the state of their origin. Consequently a multiple corporation is said to be strbject to all the privileges and obligations imposed upon domestic corporations in each charter state. ${ }^{45}$ But such corporations are not entitled to exercise in one charter state privileges granted in another ; $^{\mathbf{6}}$ and in some instance they have escaped obligations imposed by charter states by convincing the courts that they were not corporations organized under the laws of the state within the meaning of the regulatory statute. ${ }^{47}$ Because of the fact that a multiple corporation is considered a domestic corporation in each charter state, many unusual legal problems have arisen.

Federal Jurisdiction. The most prolific source of litigation involving multiple corporations has been the question of federal jurisdiction based upon

44 Fed. 513 (C. C. Ind. 1890); Winn v. Wabash R. R., 118 Fed. 55 (C. C. W. D. Mo. 1902).

41. E.g.. Del. Laws 1935, c. 148, §6; X. Y. Raindad LaW \$140; Unifora Bus. CORP. ACT $\$ 43$.

42. E.g., Idaho Coxst. Art. xi, \$14; MEe. Rev. Stat. (1930) c. 56, \$63; VA. Code (Michie, 1930) $\S \S 3 \$ 21,3857$. Texas prohibits all domestic railroad corporations froln consolidating with foreign corporations. TEx. Coxst. art. 10, 8 .

43. U. S. Cosst. Art. I, $\$ 10(3)$. Ohio \& Miss. Ry. v. People, 123 Ill. 467, 14 N. E. 874 (1888). But see Brockett v. Ohio \& Pa. R. R., 14 Pa. 241, 244 (1850).

44. Ohio \& Miss. R. R. v. Wheeler, 1 Black 286 (U.S. 1862); Quincy R. R. Bridge Co. v. Adams Co., 88 I1l. 615 (1878); Chicago \& N. W. R. R. v. Auditor General, 53 Mrich. 79, 18 N.W. 586 (1884).

45. Peik v. Chicago \& N. W. Ry., 94 L. S. 164 (1877) ; Stone v. Farmers Loan \& Trust Co., 116 L. S. 307 (1885); Wells Lumber Co. v. Menominee River Boom Co., 203 Mich. 14, 168 X. W. 1011 (1918) ; Sage r. Lake Shore \& M. S. Ry., 70 N. Y. 220 (1877).

46. Peik v. Chicago \& N. W. Ry., 94 U. S. 164 (1877).

47. Ohio \& Miss. Ry. v. People, 123 Ill. 467, 14 N. E. 874 (1888). Compare the cases permitting stockholders' meetings to be held in only one state, cited infra note $\mathbf{7 2}$. 
diversity of citizenship. A few well defined rules have emerged. When suit is brought against a multiple corporation in any charter state, federal jurisdiction will often depend on which entity is sued. The federal courts have resolved this problem by a conclusive presumption that the multiple corporation is domiciled in the charter state in which suit is brought, so that the requisite diversity will exist only if the plaintiff is a citizen of some other state, citizenship in another charter state sufficing for this purpose. ${ }^{48}$ When the multiple corporation is a party plaintiff, some courts have held that it may clothe itself with the name and citizenship of any of its numerous entities no matter where it brings suit." But in a recent case where a railroad incorporated in North Carolina and Virginia sued a North Carolina corporation, federal jurisdiction was denied on the ground that a multiple corporation should be presumed to be a citizen of the charter state in which suit is brought when it is suing as well as when it is sued.5 If the distinction between suits against and suits by multiple corporations is thus abandoned, it will be practically impossible for a multiple corporation to sue a citizen of any charter state in the fecleral courts, for realistic considerations usually necessitate suit in the state of which the defendant is a citizen.

Taxation. Multiple corporations afford greater opportunity for double taxation than ordinary corporations, but the courts, under the guise of statutory construction, have exhibited a reluctance to impose this burden, since it places multiple corporations at a competitive disadvantage with other business units. One potential cause of double taxation is the exaction of organization taxes by sereral states. When a multiple corporation is formed by the consolidation of corporations of two states, each state has the power to impose an organization tax upon the full amount of the capital stock, since each state is granting to the consolidated corporation the privilege of incorporating. ${ }^{51}$ Some courts. however, are willing to construe the taxing statutes so as to avoid this result. Thus, statutes imposing a tax on corporations "organized under the laws of this state" have been interpreted to

48. Railway Company v. Whitton's Administrator, 13 Wall. 270 (U. S. 1871); Patch r. Wabash R. R., 207 U. S. 277 (1907) ; Missouri Pacific Ry. v. Mech, 69 Fed. 753 (C. C. A. Sth, 1895); Lake Shore \& MI. S. Ry. v. Eder, 174 Fed. 944 (C. C. A. 6th, 1909) ; Consolidation Coal Co. v. Western XId. Ry., 44 F. (2d) 595 (Md. 1930) ; Boston \& M. R. R. v. Breslin, SO F. (2d) 749 (C. C. A. 1st, 1935).

49. Nashua \& L. R. R. v. Boston \& L. R. R., 136 U. S. 356 (1890); Chicago \& N. W. Ry. v. Chicago \& P. R. R., 5 Fed. Cas. No. 2665 (C. C. N. D. Ill. 1874) ; see WrLLIAMs, op. cit. supra note 48, at 169 ; cf. Carolina \& N. 11. Ry. v. Town of Clover, 34 F. (2d) 480 (WW. D. S. C. 1929). For the rule that a multiple corporation may not sue as a corporation chartered in two states, see Ohio \& Mliss. R. R. v. Wheeler, 1 Black: 286, 297 (U. S. 1862) ; St. Joseph \& G. I. R. R. v. Steele, 167 U. S. 659, 663 (1897).

50. Town of Bethel v. Atlantic Coast Line R. R., 81 F. (2d) 60 (C. C. A. 4th, 1936).

51. Ashley v. Ryan, 153 U. S. 436 (1694); Ohio \& Mitss. R. R. v. Weber, 95 Ill. 443 (1880); Chicago \& E. I. R. R. v. Ketcham, 153 Ind. 134, 51 N. E. 924 (1859). 
mean organized under the laws of that state alone. ${ }^{52}$ Likewise, when corporations have been rechartered in the taxing state, the courts have generally held that the tax did not apply, either because the particular domestication statute did not create a new corporation, ${ }^{53}$ or because the tax applied only to corporations chartered there for the first time. ${ }^{54}$

Double taxation might also result from the imposition of annual franchise taxes by each charter state, measured by the total capital stock of a multiple corporation for the privilege of doing business in the corporate form. ${ }^{65}$ But many franchise taxes, especially those levied upon railroads, are by statute measured only by capital used or property owned in the state, ${ }^{, 0}$ and several state courts have arrived at the same limitation without the aid of statutes by calling the tax one upon property which is valid only on the property within the state. ${ }^{57}$

Taxation of the income and the intangible property of multiple corporations raises peculiarly difficult problems because of the general rule that the state of a corporation's domicile has power to levy such taxes. If this rule is applied to multiple corporations, and if they are considered to be domiciled in each charter state, as they are for the purpose of federal jurisdiction, each of these states might levy a tax on all intangible property and income belonging to the corporation. But in view of the Supreme Court's recently assumed antipathy toward double taxation, ${ }^{\text {ss }}$ this rule may not be carried to its logical extreme. One alternative would be to consider a multiple corporation as having only one domicile-perhaps the state of its principal office-for purposes of taxation. Or the multiple corporation might be recognized as several entities having separate domiciles; each entity would then be taxed on all income derived from business transacted in its own charter

52. People v. New York, C. \& St. L. R. R., 129 N. Y. 474, 29 N. E. 959 (1892); New York Central R. R. v. Flynn, 233 App. Div. 123, 251 N. Y. Supp. 343 (3d Dep't 1931).

53. Cincinnati, N. O. \& T. P. Ry. v. Commonwealth, 119 Ky. 196, 83 S. W. 562 (1904).

54. Vaughan v. Nashville, C. \& St. L. Ry., 192 Ky. 137, 232 S. W. 411 (1921); State v. Tompkins, 43 S. C. 49, 25 S. E. 982 (1896).

55. Indianapolis \& St. L. R. R. v. Vance, 96 U. S. 450 (1878); Keokuk \& Hamilton Bridge Co. v. Illinois, 175 U. S. 626 (1900); Kansas City, M. \& B. R. R. v. Stiles, 242 U. S. 111 (1916) ; State v. Atlantic Coast Line R. R., 202 Ala. 558, 81 So. 60 (1918), cert. denied, 253 U. S. 489 (1920). The issue of double taxation did not arise in these cases. See Brown, Multiple Taration by the States-What is Left of It? (1935) 48 HARv. L. REv. 407, 414.

56. See 2 Cooley, Taxation (4th ed. 1924) $\$ \S 815,817$.

57. Chicago \& N. W. Ry. v. Auditor General, 53 Mich. 79, 18 N. W. 586 (1884); Easton Delaware Bridge Co. v. Metz, 32 N. J. L. 199 (Sup. Ct. 1867); Commonwealth v. President, Manager \& Company, 9 Axr. L. Reg. 298 (Pa. C. P. 1860); see State Treasurer v. Auditor General, 48 Mich. 224, 231, 9 N. W. 258, 260 (1881).

58. Farmers Loan \& Trust Co. v. Minnesota, 280 U. S. 204 (1930); Baldwin v. Missouri, 281 U. S. 586 (1930); see Harding, Double Taxation of Promerty AND InCOME (1933) ; Merrill, Jurisdiction to Tax-Another Word (1933) 44 Y ALE L. J. 582. 
state and on all the intangibles which could be given a situs there; while as to income and intangibles attributable to non-cluarter states and intangibles for which no situs could be found, each entity might be taxed for a share computed by dividing the total among all the entities either equally or according to the respective contributions of each entity to the total volume of business.

MIultiple corporations have been concerned with the danger that each charter state might levy a succession or transfer tax upon all outstanding shares of stock, for such taxes would tend to raise the cost of obtaining capital by rendering the corporation's shares a less desirable investment. ${ }^{3}$ In view, however, of the recent Supreme Court holding in First National Bank of Boston v. Maine, ${ }^{60}$ that the shares of a corporation owned by $a$ nonresident decedent are not taxable by the state of incorporation, the power of two charter states to levy a succession tax on the same shares would no longer seem to exist. But the possibility still remains that each charter state might levy a transfer tax on the shares of multiple corporations. ${ }^{61}$

Responsibility for Acts of MIultiple Corporations. It seems clear that acts done on behalf of multiple corporations bind all entities. Thus, a multiple corporation is subject to garnishment in one charter state for wages due for work done in another ${ }^{62}$ and may be sued in one charter state on tort or contract claims or judgments incurred in another. ${ }^{.3}$ Furthermore, a court in a charter state which has acquired jurisdiction over such a corporation may order the sale of all corporate property at foreclosure even though part is situated in other charter states. ${ }^{\text {at }}$

59. The power of one charter state to lewy a succession tax has been upheld on several occasions. Northern Central Ry. v. Fidelity Trust Co., 152 1fd. 94, 136 Atl. 66 (1927) ; Welch v. Treasurer \& Receiver General, 223 11ass. 87, 111 N. E. 774 (1916). But $c f$. Rhode Island Hospital Trust Co. v. Doughton, 270 U. S. 69 (1926).

60. 284 U. S. 312 (1932). But see Brown, suira note 55, at 414.

61. See First National Bank of Boston v. Maine, 284 U. S. 312, 330 (1932); Lowndes, The Passing of Situs-Jitrisdiction to Tax Shares of Corporatc Slocl: (1932) 45 HARv. L. REv. 777, 786.

62. Johnson v. Union Pacific R. R., 145 Fed. 249 (C. C. R. I. 1905); Georgia \& A. Ry. v. Stollenwerck, 122 Ala. 539, 25 So. 258 (1899). But see Tourville v. Wabash R. R., 148 Mo. 614, 622, 50 S. IV. 300, 301 (1899).

63. Smith v. New York, N. H. \& H. R. R., 96 Fed. 504 (C. C. Mass. 1899) (tort); Boston \& Maine R. R. v. Breslin, 80 F. (2d) 749 (C. C. A. 1st, 1935), cert. denicd, 297 U. S. 715 (1936) (tort); Fitzgerald v. Missouri Pac. Ry., 45 Fed. 812 (C. C. Neb. 1891) (contract); Riverdale Cotton Mills v. Alabama \& Georgia Mfg. Co., 193 U. S. 188 (1905) (judgment).

64. Muller v. Dows, 94 U. S. 444 (1876) ; Blackburn v. Selma, M. \& M. K. R., 3 Fed. Cas. No. 1467 (C. C. W. D. Tenn. 1879). Compare State v. Northern Central Ry., is Mrd. 193 (1861) (courts of one charter state may appoint receiver for entire road), with Matter of Cooley, 186 N. Y. 220, 229, 78 N. E. 939, 941 (1906) (property in each charter state must be administered by receiver appointed by courts of that state). 
But the courts have been uncertain in selecting the theory on which this result may be reached. Instead of considering all the entities joint operators of the whole enterprise, they have attacked the problem with presumptions, as in the cases involving federal jurisdiction. The traditional presumption is that the entity created by one charter state is the one performing all acts in that state. ${ }^{65}$ Resort is then had to principles of agency, joint adventure, or partnership to bind all the other entities. ${ }^{66} \mathrm{~A}$ few courts, however, have been unable to find any theory by which to bind one entity for acts done by the other. ${ }^{6 i}$ The modern riew cures this deficiency by a presumption that the corporation created by the forum state owns and operates the properties in all the states, charter and non-charter, thus ignoring the other entities completely. ${ }^{68}$

Stockholders' Meetings. Since ordinary corporations may not hold stockholders' meetings outside the charter state either for organization ${ }^{69}$ or any other purpose ${ }^{\mathbf{7 0}}$ without express statutory authorization, it has been argued that no valid obligation, in the case of a multiple corporation, is created unless authorized by successive meetings in each charter state. But the courts have unanimously repudiated this contention. holling that a meeting in any charter state for organization ${ }^{71}$ or any other purpose ${ }^{72}$ may create obligations binding in every charter state. The question of what law should govern the method of calling the meeting has, however, remained unsettled, and in

65. Muller v. Dows, 94 U. S. 444 (1876) ; Memphis \& C. R. R. v. Alabama, 107 U. S. 581 (1882); Patch v. Wabash R. R., 277 U. S. 227 (1907); Stout v. Sioux City \& P. R. R., 8 Fed. 794 (C. C. D. Neb. 1881) ; Missouri Pac. Ry. v. Meeh, 69 Fed. 753 (C. C. A. 8th, 1895).

66. In $r c$ Boston, H. \& E. R. R., 3 Fed. Cas. No. 1677 (C. C. D. Conn. 1871); Fitzgerald v. Missouri Pac. Ry., 45 Fed. 812 (C. C. D. Neb. 1891); Smith v. New York, N. H. \& H. R. R., 96 Fed. 504 (C. C. D. Mass. 1899); Newport \& Cincinnati Bridge Co. v. Woolley, $78 \mathrm{Ky} .523$ (1880).

67. Kahl v. Memphis \& C. R. R., 95 Ala. 337, 10 So. 661 (1891); see Tourville v. Wabash R. R., 148 Mo. 614, 622, 50 S. W. 300, 301 (1899).

68. Lake Shore \& M. S. Ry. v. Eder, 174 Fed. 944 (C. C. A. 6th, 1909); Case v. Atlanta \& C. A. L. Ry., 225 Fed. 862 (IV. D. S. C. 1915) ; Boston \& M. R. R. v. Breslin, 80 F. (2d) 749 (C. C. A. 1st, 1935), cert. denicd, 297 U. S. 715 (1936).

69. Duke v. Taylor, 37 Fla. 64, 19 So. 172 (1896).

70. American Clearing Co. v. Walkill Stock Farms Co., 293 Fed. 58 (S. D. Fla. 1923) ; Reichwald v. Commercial Hotel Co., 106 Ill. 439 (1883).

71. Winn v. Wabash R. R., 118 Fed. 55 (C. C. W. D. Mo. 1902). Where multiple incorporation occurs by rechartering, no organization meeting is necessary to accept the new charter. Western \& A. R. R. v. Roberson, 61 Fed. 592 (C. C. A. 6th, 1894); see Louisville Trust Co. v. Louisville, N. A. \& C. Ry., 75 Fed. 433, 443 (C. C. A. 6th, 1896).

72. Graham v. Boston, H. \& E. R. R., 118 U. S. 161 (1886); Brown v. Boston \& M. R. R., 233 Mass. 502, 124 N. E. 322 (1919); Covington \& Cincinnati Bridge Co. v. Mayer, 31 Ohio St. 317 (1877); see Restatexext, Conflict of Laws (1934) \$204; Foley, Incorporation, Multiple Incorporation and the Conflict of Lazes (1929) $42 \mathrm{HARv}$. L. Rev. 516, 524. 
view of the dearth of authority on the subject, ${ }^{73}$ it would seem advisable to satisfy the requirements of every charter state. But once the meeting is assembled, its conduct is guided by the law of the charter state in which it is held. ${ }^{74}$

Ultra vires. The difficulties of multiple corporations concerning the doctrine of ultra vires, are caused by the fact that the powers conferred on these corporations are frequently broader under one charter than under another. ${ }^{75}$ Where the issue of ultra vires is raised before the conteniplated action is carried out the applicable legal doctrine is relatively simple: If the act will affect the corporation in only one charter state, it need be authorized by that state alone. ${ }^{76}$ But if the proposed act will affect the corporation as a whole and is not authorized under each charter, it will generally be enjoined at the suit of a stockholder ${ }^{77}$ or of the attorney-general ${ }^{78}$ in any charter state. One court, however, has said that acts authorized under one charter are authorized under all. ${ }^{79}$ The problem is likely to become acute in financing operations which usually affect the whole line. Thus, a railroad incorporated in six states, which wished to issue convertible bonds was forced to induce the legislatures of all six states to amend their corporation laws in order to secure the requisite power under the charter of each state. ${ }^{80}$

When action not authorized in every charter state has actually been carried out, other rules govern. If suit is brought in a state in which the act

73. What little authority there is suggests that the method of calling the meeting is governed by the law of the charter state in which the meeting is to be held. See Pollitz v. Wabash R. R., 150 App. Div. 709, 712, 135 N. Y. Supp. 785, 787 (1st Dep't 1912); RestateMient, Conflict of L.aws (1934) $\$ 204$.

74. Brown v. Boston \& Maine R. R., 233 Mass. 502, 124 N. E. 322 (1919); see Restateasent, Confi.ict of Laws (1934) \$204; Foley, sutra note 72, at 525.

75. Cf. Louisville, N. A. \& C. Ry. v. Louisville Trust Co., 174 U. S. 552 (1893); Miackay v. New York, N. H. \& H. R. R., \&2 Conn. 73, 72 Atl. 583 (1909); Attorney General v. New York, N. H. \& H. R. R., 198 Mass. 413, 84 N. E. 737 (1903).

76. Clark v. Barnard, 108 U. S. 436 (1883); Attorney General v. Boston \& Maine R. R., 109 Mass. 99 (1871); see Attorney General v. New York, N. H. \& H. R. R, 198 Mass. 413, 84 N. E. 737 (1908); Boston \& Mfaine R. R., 3 Op. Att. Gen. 199, 205 (Mass. 1909).

77. Bulkeley v. New York, N. H. \& H. R. R., 216 MFass. 432, 103 N. E. 1033 (1914) ; Pollitz v. Public Utilities Comm. of Ohio, 96 Ol. St. 49, 117 N. E. 149 (1917); see Continental Securities Co. v. New York C. \& H. R. R. R., 217 N. Y. 119, 126, 111 N. E. 484,486 (1916).

78. Ohio \& Miss. Ry. v. People, 123 Ill. 467,14 N. E. 874 (188S) ; Attomey General v. New York, N. H. \& H. R. R., 198 Mass. 413, 84 N. E. 737 (1903).

79. See Covington \& Cincinnati Bridge Co. v. Mrayer, 31 Ohio St. 317,325 (1877). When an association already incorporated by one state is reincorporated by another, there is some authority holding that the creation of shares is governed by the law of the state which first incorporated the association. Grangers' Life \& Hcalth Ins. Co. v. Kamper, 73 Ala. 325 (1882); Covington v. Covington \& Cineinnati Bridge Co., 10 Bush. 69 (Ky. 1873); Restatearent, Conflict of LAws (1934) $\$ 205$; Foley, sugra note 72 , at 541 .

80. This was the experience of the New York Central Railroad in 1934. 
is intra vires, the act will be held to have created a valid obligation on the entire property, ${ }^{81}$ even though the judgment may not be recognized in charter states where the act is ultra vires. ${ }^{82}$ But if suit is brought in a state in which the act is ultra vires the courts have been almost as anxiouts to apply local law and have ignored the fact that it might be intra vires under the laws of some other charter state. ${ }^{83}$ In determining the issue of ultra vircs, however, the courts appear reluctant to hold the act unauthorized in the absence of specific statutory prohibitions, ${ }^{84}$ and even these have been held inapplicable on the ground that the legislature impliedly consented that they should not apply to multiple corporations. ${ }^{85}$ Where suit is brought in a non-charter state, there is no conflict between local and foreign law, and as might be expected, the results are more equitable. In this situation, the courts have enjoined threatened action that was not intra vircs inder all charters, ${ }^{86}$ but have called the executed acts intra vires if they were authorized by any charter state. ${ }^{87}$

\section{CONCLUSION}

From a survey of these problems it would seem that the disadvantages of doing business as a multiple corporation outweigh the advantages - a view substantiated by the fact that multiple corporations are practically nonexistent save in the railroad field. ${ }^{88}$ It by no means follows, however, that

81. Clark v. Barnard, 108 U. S. 436 (1883); Mackay v. New York, N. H. \& H. R. R., 82 Conn. 73, 72 Atl. 583 (1909).

82. Alabama \& Georgia Mfg. Co. v. Riverdale Cotton Mills, 127 Fed. 497 (C. C. A. 5th, 1904); Pittsburgh \& S. L. R. R.'s Appeal, 4 Atl. 385 (Pa. 1886). Contra: Riverdale Cotton Mills v. Alabama \& Georgia Mfg. Co., 198 U. S. 188 (1905).

83. Farnum v. Blackstone Canal Corp., 8 Fed. Cas. No. 4,675 (C. C. R. I. 1830); Attorney General v. New York, N. H. \& H. R. R., 198 Mass. 413, 84 N. E. 737 (1908); Blue Ridge Power Co. v. Southern Ry., 122 S. C. 222, 115 S. E. 306 (1922). Where suit is brought in a federal court by reason of diversity of citizenship, the court has refused to consider that the act was intra zires in another charter state, for this would have the effect of bringing the corporation of another state before the court and would often defeat diversity jurisdiction. Pennsylvania R. R. v. St. Louis, A. \& T. H. R. R., 118 U. S. 290 (1886) ; cf. Alabama \& Georgia Mfg. Co. v. Riverdale Cotton Mills, 127 Fed. 497 (C. C. A. 5th, 1904).

84. Continental Trust Co. v. Toledo, St. L. \& K. C. R. R., 86 Fed. 929 (C. C. N. D. Ohio 1898), aff'd, 95 Fed. 497 (C. C. A. 6th, 1899), cert. denicd, 176 U. S. 219 (1900); Boston \& M. R. R., 3 Op. Att. Gen. 199 (Mass. 1909).

85. Southern Ry. v. Lancaster, 149 Ga. 434, 100 S. E. 380 (1919); Ohio \& Miss. Ry. v. People, 123 IIl. 467,14 N. E. 874 (1888); Attorney General v. Boston \& M. R. R., 109 Mass. 99 (1871).

86. Fisk v. Chicago, R. I. \& P. R. R., 53 Barb. 513 (N. Y. Sup. Ct. 1868) ; Pollitz v. Wabash R. R., 150 App. Div. 709, 135 N. Y. Supp. 785 (1st Dep't 1912).

87. Bachman v. Supreme Lodge Knights \& Ladies of Honor, 44 Ill. App. 188 (1892); Martinez v. Supreme Lodge of Knights, 81 Mo. App. 590 (1899), (1900) 13 HARV. L. REv. 597.

88. A survey of Moody's manuals has revealed no multiple corporations among the industrial and public utility corporations and only 68 among the railroads. 
multiple corporations should be abolished by such a device as federal incorporation, especially since the solution for some of the problems may be found in federal legislation of a less drastic type.

For instance, to alleviate one of the most serious problems faced by multiply incorporated railroads, namely the necessity of securing charter power to issue securities from each charter state, Congress might exercise its plenary power over interstate commerce to relieve the carriers from these state restrictions. ${ }^{89}$ Although early decisions, influenced by Marshall's restrictive theory of corporations, upheld the power of a state to condition a gift of corporate power as it saw fit, even though the recipient was engaged in interstate commerce, ${ }^{00}$ subsequent Congressional legislation has occasioned a substantial regression from this position. Thus, federal intervention into the management of state corporations has been sustained on the ground that Congress has the same power over instrumentalities of interstate commerce that it would have if the corporation had been created by act of Congress, 91 and on this theory Congressional power to relieve railroads from charter obligations burdening interstate commerce has been upheld.92 Furthermore, the doctrine of unconstitutional conditions might be invoked to prevent the states from conditioning their grant of corporate powers so as to thwart federal control over interstate commerce. ${ }^{.3}$

Even this type of legislation may, however, be unnecessary, since there is considerable support for the view that Section $20 \mathrm{a}$ of the Transportation Act, ${ }^{94}$ which grants to the Interstate Commerce Commission the right to supervise the issuance of railroad securities, supplies a lack of corporate powers. Although the Act, like most federal commerce legislation, does not expressly negative continued state activity, the only affirmatively author-

89. A federal statute has been upheld as constitutional which conferred upon a state corporation power which it lacked under its state charter. Sinling Fund Cases, 99 U. S. 700 (1878). But the congressional grant of new corporate powers was approved and confirmed by the state. Id. at 727-31.

90. State Tax on Railway Gross Receipts, 15 Wall. 284 (U. S. 1873) (franchise tax on gross receipts from interstate commerce); Railroad Company v. Marjland, 21 Wall. 456 (U. S. 1874) (state may regulate interstate rates if charter so provides); Louisville \& N. R. R. v. Kentucky, 161 U. S. 677 (1896) (state may prevent consolidation of interstate railroads).

91. Hale v. Henkel, 201 U. S. 43 (1906); Interstate Commerce Commission v. Goodrich Transit Co., 224 U. S. 194 (1912).

92. New York v. United States, 257 U. S. 591 (1922) ; Colorado v. United States, 271 U. S. 153 (1926); Texas v. United States, 292 U. S. 522 (1934).

93. The doctrine has been applied in an ever-widening field. See Hale, Unconstifutional Conditions and Constitutional Rights (1935) 35 CoL L. Rev. 321; Merrill, Unconstitutional Conditions (1929) 77 U. of PA. L. REv. 879. An analogy has been drawn from this doctrine in limiting the Commission's authority to condition its approval of re-organization plans. United States v. Chicago, Mi., St. P. \& P. R. R., 282 U. S. 311, 328 (1931).

94. 41 Stat. 494 (1920), 49 U. S. C. 202 (1934). 
ized participation by the states in the regulation of securities is of a purely advisory character. ${ }^{95}$ And although the Act apparently does not preclude the states from exacting the usual fees for charter amendments, ${ }^{00}$ the only limitation of state law actually binding on the Commission is that the securities be issued "for some lawful object within its corporate purposes." Since the Act speaks of corporate purposes and not powers, it would seem that Commission approval of an issue of securities under Section 20a might supply whatever powers are lacking under state charters to issue the securities in question. ${ }^{98}$ Indeed, a recent Supreme Court decision suggests that in view of the expressed legislative intent to make the Commission's power plenary, Congress did not intend to bind the Commission to follow limitations imposed on corporate powers by state law. ${ }^{99}$

The Commission itself has neither accepted nor rejected this interpretation of the Section. Rather it has announced that it will follow state law "without deciding to what extent our power with respect to an issue of securities is affected by the limitation of a State regulation." 100 Thus, the Commission has been governed in the past by state laws prohibiting the issuance of securities below par ${ }^{101}$ and by other state regulations. ${ }^{102}$ By this policy the Commission seems to have emasculated its own powers. But it may take little argument to convince the Commission that corporate powers might be conferred on a carrier by an order issuẹd under Section 20a, for one commissioner seems to have been in sympathy with this view when, in a dissenting opinion, he suggested that a carrier might apply directly to the Commission for a grant of charter powers. ${ }^{103}$

95. State authorities are authorized to make representations before the Commission for the protection of "the rights and interests of their people and the States." 41 Stat. 495 (1920), 49 U. S. C. 20 a (b) (1934).

96. Chicago \& E. I. Ry. v. Emmerson, 327 Ill. 574, 158 N. E. 857 (1927), ccrt. dcuied, 277 U. S. 601 (1928).

97. 41 Stat. 495 (1920), 49 U. S. C. 20 a (2) (1934).

98. See New York Central Securities Corp. v. United States, 54 F. (2d) 122, 130 (S. D. N. Y. 1931) ; Public Service Comm. v. Northern Central Ry., 146 Md. 580, 592, 127 Atl. 112, 117 (1924); 2 Sharmian, The Interstate Commerce Commission (1931) 249 ; cf. Reynolds, Distribution of Power to Regulate Interstate Carriers Between the Nation and the States (1928) 354, 368.

99. See New York Central Securities Corp. v. United States, 287 U. S. 12, 27 (1932) ; cf. Texas v. United States, 292 U. S. 522 (1934).

100. See Capital Stock of Pittshurgh \& WV. V. Ry., 82 I. C. C. 704, 706 (1923).

101. Capital Stock of Pittsburgh \& W. V. Ry., 82 I. C. C. 704 (1923); Stock of Castleman R. R., 90 I. C. C. 521 (1924).

102. Securities of St. Louis-S. F. Ry. and Certain Subsidiaries, 79 I. C. C. 323 (1923) ; Stock of Old Colony R. R., 124 I. C. C. 239 (1927); see LockLiN, REgulation of SeCURIty Issues (1927) c. 2; 2 Sharfman, op. cit. supra note 98, at 247-258. When the carrier's corporate capacity to issue securities is in doubt, the Commission will accept the opinion of the carrier's counsel. Assumption of Obligation and Liability by New York Central R. R., 158 I. C. C. 317 (1929).

103. See Construction of Cut-Off for Illinois Central R. R., 82 I. C. C. 100,117 (1923). 
Existing legislation may be of further assistance in permitting railroads to be consolidated by devices other than multiple incorporation. Prior to 1920 , when state statutes either did not grant or expressly denied corporations the power to carry out interstate unifications by sale, lease, or stock ownership, unifications were often achieved by statutory consolidation between corporations of two states which resulted in multiple incorporation. The Transportation Act of 1920 , however, gave the Commission authority to approve unifications of railroads ${ }^{10 \pm}$ and relieved the carriers from all restraints and prohibitions of state or federal law in so far as was necessary to perform an act approved by the Commission. ${ }^{103}$ Cnder these provisions it seems clear that Commission approval to lease or operate another railroad supersedes such state statutes as those prohibiting foreign railway corporations from operating in the state ${ }^{100}$ or those prohibiting domestic railways from leasing or selling their assets and franchise to foreign corporations. ${ }^{107}$ If Commission approval obviates all difficulties where corporate power is expressly negatived, it would clearly seem to do so where such power is merely lacking under charter provisions. A contrary view would render unattainable one of the chief results which Congress sought, namely the desire to confer upon the Commission complete control of consolidations unhampered by state law.108 The Supreme Court has apparently leaned toward this view, for it has said that Congress did not intend that the Commission should determine whether the contemplated carrier action was within its state charter power before issuing an order. ${ }^{109}$ With state restrictions removed and a lack of corporate power remedied, the carriers may achieve unification by sale, lease, or stock ownership which do not result in multiple incorporation.

But for corporations desiring to unify by statutory consolidation, federal legislation has not been and probably will not be of much assistance in preventing the emergence of multiple corporations. The Act of 1920 pro-

104. 41 Stat. 481 (1920), as amended, 48 StAт. 217 (1933), 49 U. S. C. \$ 5(4) (1934).

105. 41 Stat. 482 (1920), 49 U. S. C. $\$ 5$ (15) (1934).

106. Missouri Pac. R. R. Unification, 166 I. C. C. 154 (1930); Texarkana \& T. S. Ry. Control, 189 I. C. C. 253 (1932). The latter case was affirmed by the Supreme Court, but Texas did not contest the Commission's ruling that its statute was inefiective to prevent foreign corporations from operating in the state. Texas v. Lnited States, 292 U. S. 522 (1934).

107. Rock Island System Consolidation, 193 I. C. C. 395 (1933): sce unreported cases cited in Simpson. The Interstate Commerce Commission and Railroad Consolidation (1929) 43 Harr. L. Rev. 192, 241, n. 247.

108. See Hcarings before Committee on Intcrstate Commerce ons $S .813$, and $S$. 844 , 73d Cong., 1st Sess. (1933) 53; Simpson, supra note 107, at 242; Comment (1931) 31 CoL. L. Rev. 651 . But see Quarles, Consolidation of Interstate Railreads (1933) $20 \mathrm{VA}$. L. REv. 200.

109. Cleveland, C. C. \& St. L. Ky. v. United States, 275 U. S. 404 (1928); ClaitorneAnnapolis Ferry Co. v. United States, 285 U. S. 382 (1932); N. Y. Central Securities Corp. v. United States, 287 U. S. 12 (1932). 